\title{
Antibody to Human Follicle-Stimulating Hormone: Cross-Reactivity with Three Other Hormones
}

\author{
Sheldon Schlaff, Saul W. Rosen, and Jesse Roth \\ From the Clinical Endocrinology Branch, National Institute of Arthritis \\ and Metabolic Diseases, Bethesda, Maryland 20014
}

A в S T R A C T Antibodies directed against human follicle-stimulating hormone ( $\mathrm{FSH}$ ) were demonstrated in rabbit serum by neutralization of biological activity. Antibodies that bound $\mathrm{FSH}^{-131} \mathrm{I}$ were produced in rabbits and guinea pigs by repeated injections of FSH. By ${ }^{131} \mathrm{I}$ immunochemical methods, we found that at least $90 \%$ of the FSH-131-binding antibody failed to distinguish the four human glycoprotein hormones: FSH, luteinizing hormone, chorionic gonadotropin, and thyrotropin, purified as well as endogenous hormone in plasma. Neither growth hormone, adrenocorticotropin, nor a variety of glycoproteins or animal plasmas were able to react with these antibodies.

\section{INTRODUCTION}

Because the pituitary gonadotropins, folliclestimulating hormone ( $\mathrm{FSH})$, and luteinizing hormone (LH) have routinely been measured by tedious, imprecise, and relatively insensitive bioassays on extracts of urine, many workers are investigating ${ }^{131} \mathrm{I}$-immunoassay methods (2) for the measurement of gonadotropins in plasma. In attempting to develop such an assay for plasma $\mathrm{FSH}$, we noted that rabbit and guinea pig antiFSH reacted not just with FSH but with three other glycoprotein trophic hormones: LH, thyrotropin (TSH), and human chorionic gonadotropin

This work was reported in part at the Annual Meeting of the American Federation for Clinical Research, Atlantic City, N. J., May 1967 (1).

Received for publication 17 October 1967 and in revised form 6 March 1968.
(HCG). We report here the results of studies of this unusual cross-reaction.

\section{METHODS}

Hormones and plasmas were of human origin except as noted. Biologic potency of the FSH preparations ${ }^{1}$ listed in Fig. 1 was measured by the rat ovarian weight augmentation assay (3) ; FSH from sheep pituitaries $\left(\mathrm{NIH}-\mathrm{FSH}-\mathrm{S}_{1}\right)^{2}$ was used as a standard, and the data were expressed in International Units (IU). ${ }^{3} \mathrm{FSH}$ (PC21-8A1) was prepared by Dr. Peter Condliffe by extraction of an acetone powder of human pituitary glands with $57 \%$ ethanol-5\% sodium chloride, by gel filtration of the dialyzed extract on Sephadex G-50, followed by chromatography on carboxymethyl cellulose. Material unadsorbed from a solution of $0.01 \mathrm{M}$ ammonium acetate, $\mathrm{pH} 5.3$ (PC-21-8A1), was further purified by filtration on Sephadex G-100 (T-II). Thyrotropin (TSH), $10 \mathrm{IU} / \mathrm{mg}, 4$ luteinizing hormone $(\mathrm{LH}), 5 \mathrm{NIH}-\mathrm{LH}-\mathrm{S}_{1} \mathrm{U} / \mathrm{mg}^{5}{ }^{5}$ and human chorionic gonadotropin $(\mathrm{HCG})^{6}$ were not further

${ }^{1}$ Gifts of Dr. Leo Reichert (LER), Department of Biochemistry, Emory University, Atlanta, Ga., through the National Pituitary Agency, Baltimore, Md., Dr. Peter Condliffe (PC), National Institute of Arthritis and Metabolic Diseases, Bethesda, Md., and Cutter Laboratories (urinary menopausal gonadotropin as Pergonal), Berkeley, Calif.

2 A gift of the Endocrinology Study Section, National Institute of Arthritis and Metabolic Diseases.

$31 \mathrm{U}(1 \mathrm{mg})$ of NIH-FSH-S $\mathrm{S}_{1}$ is approximately equivalent to 25 IU of the Second International Reference Preparation of Human Menopasual Gonadotropin.

4 A gift of Dr. Peter Condliffe.

5 Donated by Dr. Anne Stockell Hartree, Department of Biochemistry, University of Cambridge, Cambridge, England.

${ }^{6}$ Gifts of HCG were received from: Dr. K. D. Bagshawe, Edgar Laboratory, Charing Cross Hospital Group London, England (19,000 IU/mg) ; Dr. Herman Cohen, Princeton Laboratories, Princeton, N. J. (9000 IU/mg); Ayerst Laboratories, New York, (APL: $2700 \mathrm{IU} / \mathrm{mg}$ ); 
purified. Rabbit gamma globulin (RGG) was purified by chromatography on diethylaminoethyl cellulose.7

Antibodies to $\mathrm{FSH}$ were induced in rabbits (New Zealand strain, $1.5 \mathrm{~kg}$ ) and guinea pigs (both National Institutes of Health [NIH] and Hartley strains, $250 \mathrm{~g}$ ) with either PC-21-8A1 or LER 677-4. The hormones, 1 $\mathrm{mg} / \mathrm{ml}$ in saline, were emulsified with an equal volume of Freund's complete adjuvant 8 and 5-15 IU injected subcutaneously at intervals of 2 or more wk for five or more injections. The animals were bled 2 wk after the fifth and subsequent injections. Antisera to rabbit and to guinea pig gamma globulin ${ }^{9}$ were obtained from sheep after intramuscular injections of $100 \mathrm{mg}$.

FSH (Reichert, LER 710-2), LH (Hartree), and HCG (Bagshawe) were iodinated with carrier-free 10 ${ }^{181}$ iodide to specific activities of $100-150 \mu \mathrm{c} / \mu \mathrm{g}$ and human serum albumin (HSA) ${ }^{11}$ and RGG (Metzger) to specific activities of $10-20 \mu \mathrm{c} / \mu \mathrm{g}$ by the chloramine-T method (4). Unreacted iodide was removed by batch adsorption with an anion exchange resin (Dowex 1-X10); other minor radioactive contaminants were removed by gel filtration on Sephadex G-100 or by electrophoresis in starch gel.

The diluent for all experiments was sodium phosphate buffer ( 0.05 moles/liter, $\mathrm{pH} 7.4)$ to which was added bovine serum albumin $(2.5 \mathrm{mg} / \mathrm{ml})$, sodium azide $(1.0$ $\mathrm{mg} / \mathrm{ml}$ ), and plasma from a patient with panhypopituitarism at a final dilution of $1: 100$. For the assay of FSH a series of solutions were prepared each of which contained FSH- ${ }^{131} \mathrm{I}(0.05-0.1 \mathrm{~m} \mu \mathrm{g} / \mathrm{ml})$, rabbit anti-FSH (usually at a final dilution of $1: 100,000$ ), and unlabeled FSH (over the range of $0-100 \mathrm{~m} \mu \mathrm{g} / \mathrm{ml}$ ). The total volume of each solution was $1.0 \mathrm{ml}$. After 4 days at $4^{\circ} \mathrm{C}$, $0.15 \mathrm{ml}$ of sheep anti-RGG and $0.1 \mathrm{ml}$ of a $1: 20$ dilution of nonimmune rabbit plasma containing $0.1 \mathrm{M}$ ethylenediaminetetraacetate (5) were added to each solution. 1 day later the solutions were centrifuged, the supernatants discarded, and the radioactivity of the drained but unwashed sediments determined in a well-type scintillation counter. For the assay of FSH in plasma, an aliquot of plasma $(0.1 \mathrm{ml}$ or less) was substituted for the unlabeled hormone. The hormone concentration in plasma was determined by comparing radioactivity precipitated from the plasma sample with radioactivity precipitated from solutions containing known quantities of unlabeled FSH (standard curve), and was expressed in millimicrograms per milliliter of FSH (LER 710-2).

When nonimmune rabbit serum was substituted for

The Squibb Institute for Medical Research, New Brunswick, N. J. (Follutein : $2700 \mathrm{IU} / \mathrm{mg}$ ).

${ }^{7}$ A gift of Dr. Henry Metzger, National Institute of Arthritis and Metabolic Diseases.

${ }^{8}$ Difco Laboratories, Detroit, Mich.

9 Purchased as Cohn Fraction II from Hyland Laboratories, Yonkers, N. Y.

${ }^{10}$ Cambridge Nuclear Co., Cambridge, Mass., and New

England Nuclear Corp., Boston, Mass.

11 Behringwerke AG, Marburg-Lahn, Germany. the rabbit anti-FSH the sediment contained about $6 \%$ of the radioactivity, for which no correction was made. When rabbit anti-FSH serum was added in excess, 70$85 \%$ of the total radioactivity was precipitated. When RGG- ${ }^{181} \mathrm{I}$ was substituted for $\mathrm{FSH}-{ }^{181} \mathrm{I}, 71-100 \%$ of the radioactivity was precipitated. This finding suggests that in some experiments the failure to precipitate all of the FSH- ${ }^{181}$ I was due in part to failure of the sheep antiRGG to precipitate all of the RGG.

\section{RESULTS}

The purity of FSH (LER 710-2) was evaluated by vertical electrophoresis in starch gel (6) in a discontinuous buffer system (tris[hydroxymethyl] aminomethane-citrate-borate, $\mathrm{pH} 8.6$ ) and by electrophoresis in polyacrylamide gel $(7.5 \%, \mathrm{pH} 9.5)$ (7). In both systems two bands were seen with amido black 10B; the major band (about 90\%) appeared just cathodal to albumin, whereas the minor band was coincident with albumin. Assay of eluates from serial slices of an acrylamide gel showed that all of the FSH biological activity was in the major band.

Purity of the FSH-131 I was evaluated as follows: (a) FSH-131 I on electrophoresis in starch and in acrylamide had a mobility indistinguishable from that of the major band of unlabeled FSH. (b) Less than $2 \%$ of the radioactivity in starch gel electrophoresis was located in the region of LH mobility. (c) FSH-131I had less than $1 \%$ contamination with HSA-131 I on immunoelectrophoresis and precipitation with anti-HSA.

To demonstrate anti-FSH antibodies in the plasma of immune rabbits by neutralization of FSH activity several precautions were necessary. Thus, in the standard bioassay for FSH (3) intact immature rats receive $1-6$ IU of FSH and a fixed dose of HCG (e.g., $50 \mathrm{IU}$ ) ; the increase in weight of the ovaries is a function of the amount of FSH injected. However, the responsiveness of the ovaries to FSH is highly dependent on the dose of HCG, and in the absence of HCG, FSH causes no increase in ovarian weight. Since the FSH used for immunization contained $\mathrm{LH}$, the immune serum presumably also contained anti-LH antibodies which bind both LH and HCG $(8,9)$. Thus apparent neutralization of FSH activity by such an antiserum could arise either from binding of FSH or from binding of HCG. This ambiguity was avoided by using hypophysectomized immature rats since the response of the ovaries to FSH 
TABLE I

Neutralization of Biological Activity of FSH by Anti-FSH

\begin{tabular}{|c|c|c|}
\hline Solution injected & $\underset{(n=6)}{\operatorname{Ov}}$ & $\begin{array}{l}\text { weight } \\
\text { Range }\end{array}$ \\
\hline & & g \\
\hline FSH + buffer + HCG, $800 \mathrm{IU}$ & 20 & $(14-29)$ \\
\hline $\mathrm{FSH}+$ buffer $+\mathrm{HCG}, 400 \mathrm{IU}$ & 22 & $(14-29)$ \\
\hline $\mathrm{FSH}+$ nonimmune rabbit serum & & \\
\hline + HCG, $800 \mathrm{IU}$ & 21 & $(17-36)$ \\
\hline $\begin{array}{l}\text { FSH + nonimmune rabbit serum } \\
+ \text { HCG, } 800 \mathrm{IU}+\text { sheep anti- }\end{array}$ & & \\
\hline RGG & 17 & $(12-26)$ \\
\hline $\mathrm{FSH}+$ anti-FSH $+\mathrm{HCG}, 800 \mathrm{IU}$ & 8 & $(8-9)$ \\
\hline $\begin{array}{l}\text { FSH }+ \text { anti-FSH }+ \text { HCG, } 800 \mathrm{IU} \\
+ \text { sheep anti-RGG }\end{array}$ & 7 & $(7-8)$ \\
\hline HCG, 800 IU & 5 & $(3-5)$ \\
\hline Water & 3 & $(2-3)$ \\
\hline
\end{tabular}

FSH, human follicle-stimulating hormone; HCG, human chorionic gonadotropin; IU, International Units; RGG, rabbit gamma globulin.

in these animals ${ }^{12}$ is relatively insensitive to the dose of HCG, even up to 1000 IU (10).

Furthermore, because a large excess of HCG might displace antibody-bound $\mathrm{FSH}$ in vivo, the following experiments were done. FSH (LER $677-3 \mathrm{~A}, 30 \mathrm{IU})$ and rabbit serum $(0.3 \mathrm{ml})$ were incubated for $4 \mathrm{hr}$ at $24^{\circ} \mathrm{C}$. After centrifugation, aliquots of the supernatant were added to HCG, $800 \mathrm{IU}$, and injected into hypophysectomized rats. In an alternate experiment, after incubation of FSH and serum, sheep anti-RGG was added. After $24 \mathrm{hr}$ at $4^{\circ} \mathrm{C}$, the supernatant was added to HCG and injected. In both experiments, exposure of FSH to rabbit anti-FSH serum abolished biological activity (Table I), presumably due to precipitation of the FSH, whereas nonimmune rabbit serum was without effect. Since HCG at 400 and $800 \mathrm{IU}$ was in excess of the binding capacity of this serum for HCG (based on a separate determination with HCG-131I of the HCG-binding capacity) it is clear that neutralization of biological activity was due to binding of FSH by the immune rabbit serum.

FSH-131 I was bound by the antibody and displaced by unlabeled $\mathrm{FSH}$; in the presence of an excess of unlabeled hormone over $90 \%$ of the radioactivity was displaced into the supernatant

12 The use of hypophysectomized rats was suggested to us by Drs. Griff Ross and William Odell.
(Fig. 2). All preparations of FSH tested, from pituitary powder to highly purified material, yielded curves of displacement that were qualitatively identical (Fig. 1) i.e., were superimposable when the abscissa was suitably adjusted. Over a 10-20-fold range of dilution, plasma from patients with gonadal insufficiency ${ }^{13}$ or with gonadotropinproducing carcinoma of the lung (11) crossreacted identically with purified $\mathrm{FSH}$.

But highly purified preparations of $\mathrm{LH}, \mathrm{TSH}$, and HCG, containing little or no $\mathrm{FSH}$, also displaced $\mathrm{FSH}^{-131}{ }^{13}$ from the rabbit and from the guinea pig anti-FSH sera in a manner qualitatively and quantitatively identical with the displacement by pure unlabeled FSH (Fig. 2). Likewise, endogenous TSH and endogenous HCG reacted identically. ${ }^{14}$ Thus, plasma from an athyreotic prepuberal boy with $\mathrm{TSH}$ at $140 \mathrm{~m} \mu \mathrm{g} / \mathrm{ml}$ (determined by Dr. William Odell) reacted as equivalent to $114 \mathrm{~m} \mu \mathrm{g} / \mathrm{ml}$ of $\mathrm{FSH}$, and over a 30 -fold range of dilution of the plasma was indistinguishable from purified FSH (Fig. 3). Endogenous HCG in plasma from a man with choriocarcinoma and abnormally high urinary gonadotropin by bioassay was equivalent to more than $100 \mathrm{~m} \mu \mathrm{g} / \mathrm{ml}$ of $\mathrm{FSH}$ and reacted identically with FSH on dilution (Fig. 3). Furthermore, both purified $\mathrm{LH}^{-131} \mathrm{I}$ and HCG- ${ }^{131} \mathrm{I}$ bound as strongly as $\mathrm{FSH}^{-131} \mathrm{I}$ to these antisera. $\mathrm{FSH}$ and $\mathrm{LH}$ were equally potent in displacing $\mathrm{LH}^{-131} \mathrm{I}$. Thus $\mathrm{LH}$, HCG, and TSH, whether purified or in plasma, cross-reacted completely with FSH. However, a large number of other hormones, ${ }^{15}$ purified glycoproteins, ${ }^{16}$ and animal plasmas ${ }^{17}$ were without

13 Plasma from the following patients were studied over a 10-20-fold range of dilution : eight postmenopausal, one postbilateral ovariectomy, and one mixed gonadal dysgenesis (1). Plasma from one patient with Klinefelter's syndrome (47XXY) was studied over a fourfold range of dilution.

14 In addition to the data in Fig. 2, the cross-reactions were confirmed repeatedly with purified $\mathrm{LH}$ in antisera from nine rabbits and four guinea pigs, purified HCG in four rabbits, and plasma TSH in two rabbits. 15 Ovine pituitary FSH (gift of Dr. C. Cahill, Department of Chemistry, Oklahoma City University), growth hormone ( $H G H$ No. 372B2, USP U/mg, gift of Dr. A. Wilhelmi, Department of Biochemistry, Emory University, Atlanta Ga., through the National Pituitary Agency), bovine adrenocorticotropin (gift of Dr. $H$. Cohen, Princeton Laboratories).

${ }^{16}$ Bovine thyroglobulin (gift of Dr. Harold Edelhoch, National Institute of Arthritis and Metabolic Diseases), 


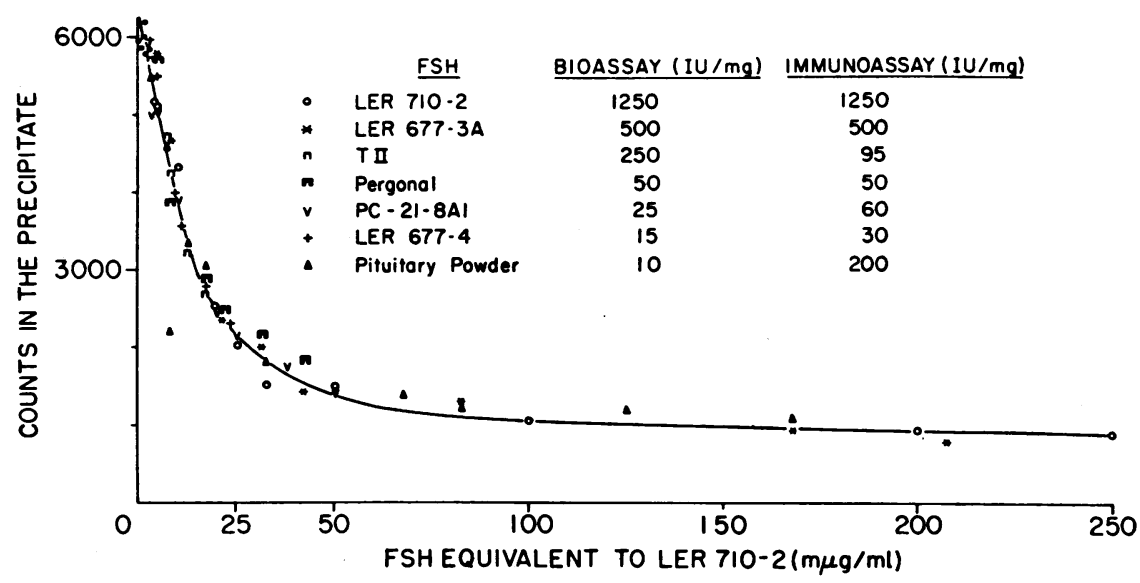

FIGURE 1 Displacement of human follicle-stimulating hormone (FSH)- ${ }^{181}$ I from anti-FSH (rabbit No. 29 November 1965, 1:100,000) by pure unlabeled FSH (LER 710-2) and by pituitary and urinary FSH preparations in different states of purity. The biological potency of the FSH preparations were measured in various laboratories (3). The immunological potency of each FSH preparations was derived by comparison (on a weight basis) of its displacement of FSH-18I to the displacement of FSH-181 I by FSH (LER-710-2).

effect. Thus, at least the vast majority of the antibody that binds $\mathrm{FSH}^{-131} \mathrm{I}$ is specific for the four hormones, though unable to distinguish among them. The results with human plasmas further

ceruloplasmin (prepared by Dr. A. Morrell, Albert Einstein College of Medicine, New York, and given to us by Dr. Gilbert Ashwell, National Institute of Arthritis and Metabolic Diseases), bovine fetuin, orosomucoid, blood group substances $\mathrm{A}$ and $\mathrm{B}$.

${ }^{17}$ Monkey (rhesus), rabbit, guinea pig, dog, cat, hog, goat, sheep, horse, burro. substantiate this conclusion, for the reactivity of human plasmas is related only to their anticipated content of these hormones (Table II).

The data from several experiments were recalculated to determine what fraction of the total FSH-131 I binding capacity was being examined (Fig. 4). The upper portion of the curve had a gentle curvature that extrapolated to yield a binding capacity of $60-70 \mu \mathrm{g}$ of hormone per $\mathrm{ml}$ of antiserum. In addition there probably was another population of antibody that had a lower affinity

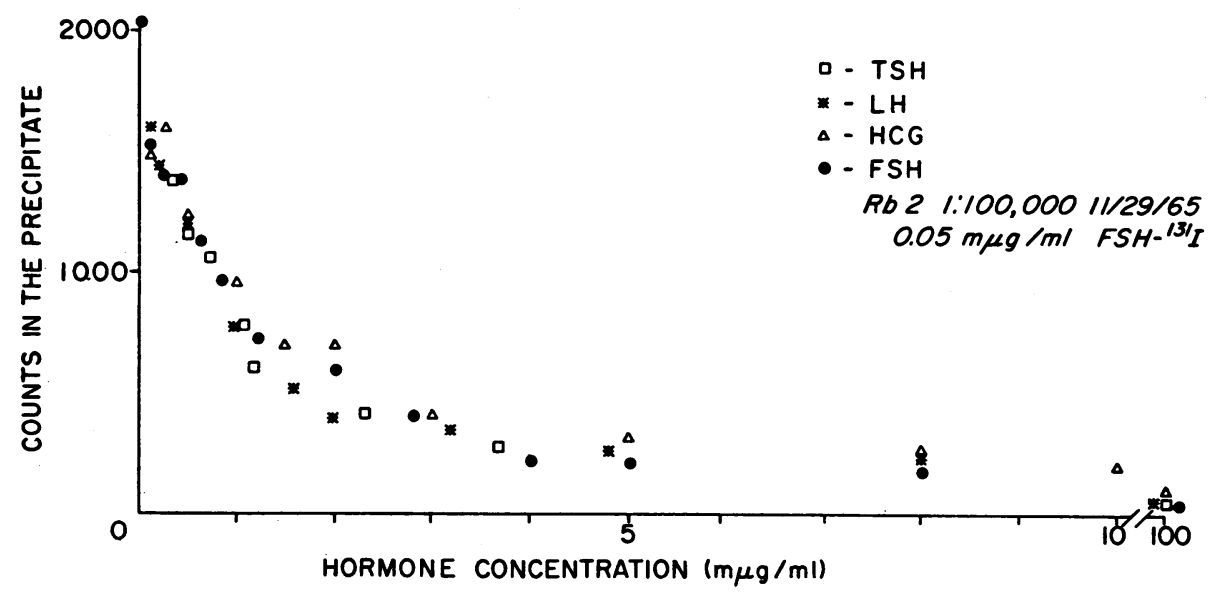

FIGURE 2 Displacement of FSH-192I from rabbit anti-FSH by purified preparations of thyrotropin (TSH) (Condliffe), luteinizing hormone (LH) (Hartree), human chorionic gonadotropin (HCG) (Bagshawe), and FSH (Reichert LER-710-2). 


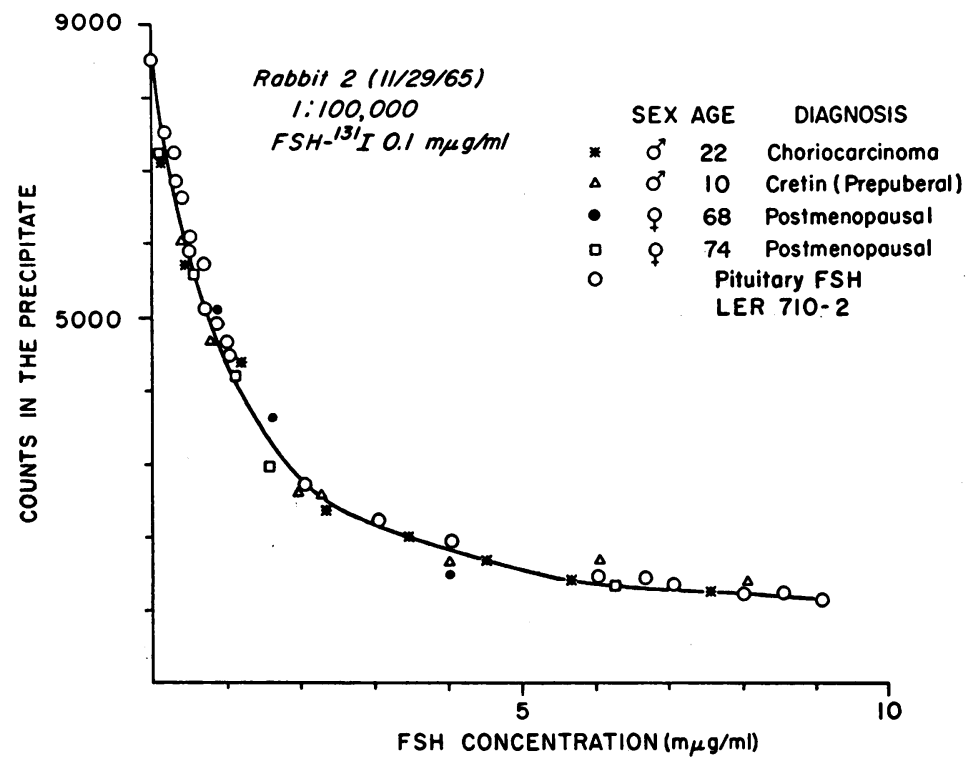

Figure 3 Displacement of $\mathrm{FSH}_{-}{ }^{181}$ I from anti-FSH by pure FSH and by plasma containing high concentrations of endogenous hormone. The abscissa, which is marked with linear increments in concentration of pituitary $\mathrm{FSH}$, also represents linear increments in the volume of each plasma. The relative scale for each of the four plasma samples was adjusted appropriately to facilitate comparison with pituitary FSH.

TABLE II

"FSH" Concentration in Plasma of Normal Adults and in Patients with Abnormal Excretion of Gonadotropins

\begin{tabular}{|c|c|c|c|c|c|c|}
\hline \multirow[b]{2}{*}{ Patients } & \multirow[b]{2}{*}{ Sex } & \multirow[b]{2}{*}{ No. } & \multirow[b]{2}{*}{ Age } & \multicolumn{3}{|c|}{ Plasma "FSH" } \\
\hline & & & & Mean & Median & Range \\
\hline \multirow{3}{*}{ Adults without endocrine disease } & & & & \multicolumn{3}{|c|}{$m \mu g / m l(L E R 780)^{*}$} \\
\hline & M & 30 & $18-88$ & 5 & 5 & $2-9$ \\
\hline & $\mathrm{F} \ddagger$ & 29 & $14-27$ & 6 & 6 & $1-9$ \\
\hline \multicolumn{7}{|l|}{ Increased urinary gonadotropins§ } \\
\hline Postmenopausal & $\mathrm{F}$ & 17 & 50-74 & 39 & 28 & $10-160$ \\
\hline Ovariectomized & $\mathrm{F}$ & 1 & 44 & $50 \|$ & & \\
\hline \multirow[t]{2}{*}{ Gonadal dysgenesis } & $45 \mathrm{XO}$ & 2 & 11,45 & 25 & & 20,30 \\
\hline & $46 X Y$ & 2 & 33,34 & 34 & & 33,35 \\
\hline \multirow[t]{2}{*}{ Klinefelter's syndrome } & $47 \mathrm{XXY}$ & 9 & $19-48$ & 21 & 18 & $10-35$ \\
\hline & $49 \mathrm{XXXXY}$ & 2 & 18,24 & 18 & & 10,26 \\
\hline \multicolumn{7}{|l|}{ Decreased urinary gonadotropins } \\
\hline Hypophysectomized $\mathbb{T}$ & $\mathrm{F}$ & 4 & $34-74$ & 2 & 2 & $1-3$ \\
\hline \multirow[t]{2}{*}{ Hypogonadal dwarfs } & M & 2 & 27,52 & 2 . & & 2 \\
\hline & $\mathrm{F}$ & 4 & $16-29$ & 3 & 3 & $2-5$ \\
\hline \multirow[t]{2}{*}{ Isolated deficiency of gonadotropin } & M & 5 & $17-36$ & 2 & 2 & $2-3$ \\
\hline & $\mathrm{F}$ & 6 & $22-57$ & 2 & 2 & $1-2$ \\
\hline
\end{tabular}

*Late in our studies the standard preparation of human follicle-stimulating hormone (FSH [LER 710-2]) lost potency. Thus the data here are reported in terms of LER-780, whose preparation and biological potency were about the same as the original LER 710-2.

$\ddagger$ Samples from the middle of the menstrual cycle were excluded.

$\$$ Assayed by the mouse uterine weight method.

\| "FSH" fell promptly to very low levels after estrogen was injected intravenously. This patient also had an isolated deficiency of thyrotropin (TSH).

I In one postmenopausal patient hypophysectomy was followed by a fall in plasma "FSH" from 30 to 1. 


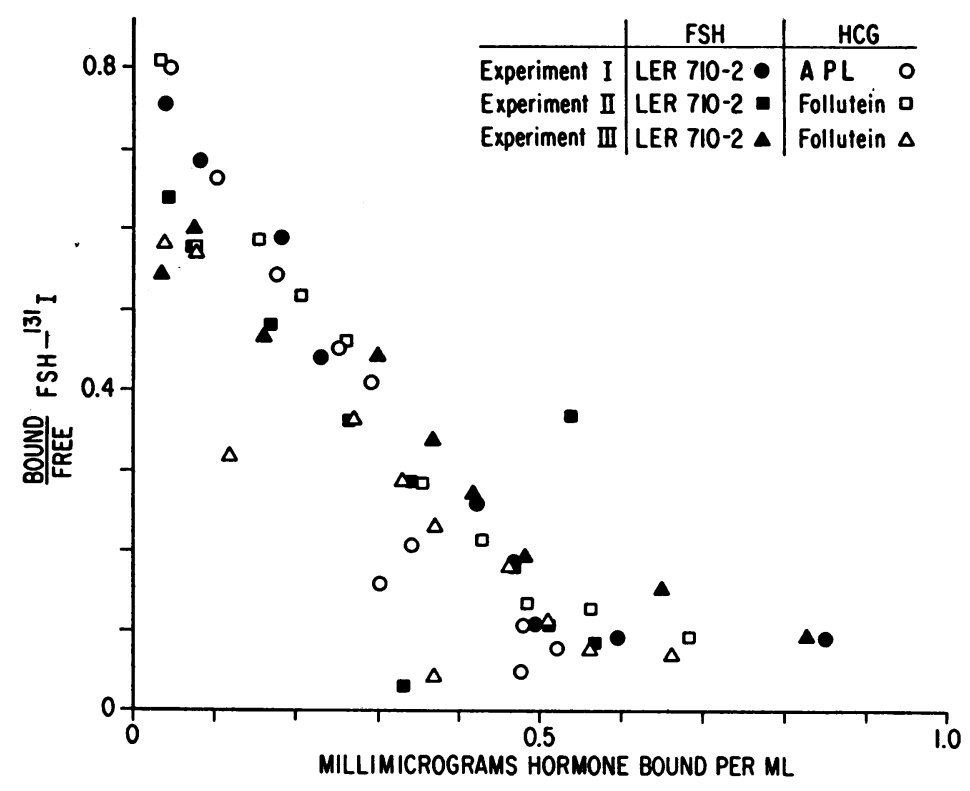

FIGURE 4 Binding capacity of antiserum for FSH and HCG. Data from three experiments with a single antiserum were combined. Corrections were applied for the radioactivity in the supernate that was immunologically unreactive and for radioactivity in the precipitate that was not bound to the antibody. The bound/ free of FSH- ${ }^{121} \mathrm{I}$ was plotted as a function of the concentration of unlabeled hormone that was bound to the FSH- ${ }^{181} I$ binding antibody $(12,13)$. Since all the experiments were performed at $1: 100,000$ dilution of antiserum, data in the figure were multiplied by $10^{5}$ to yield binding capacity per milliliter of antiserum. for the hormones with a binding capacity of 20-30 $\mu \mathrm{g} / \mathrm{ml}$ of antiserum. Both populations of antibody did not distinguish FSH from HCG. If there existed another population of $\mathrm{FSH}-{ }^{131}$ I-binding antibody, it was of very much lower affinity, or represented much less than $10 \%$ of the total binding capacity of the antibody.

\section{DISCUSSION}

Radioimmunoassay systems, in contrast to many other immunochemical methods, usually permit conclusions about antibody specificity even when not all of the components are completely pure (2). With the reservation that the specific biological activity of pure FSH is still somewhat uncertain, we conservatively assume from our data that the ${ }^{131} \mathrm{I}$ tracer is at least $80 \% \mathrm{FSH}^{-131} \mathrm{I}$, that the highly purified FSH (LER-710) is at least $80 \%$ $\mathrm{FSH}$, that the antiserum to FSH contains antiFSH antibodies (based on the biological neutralization data), and that the antiserum to $\mathrm{FSH}$ contains an antibody that binds $\mathrm{FSH}-{ }^{131} \mathrm{I}$. Since the FSH used for immunization (PC-21-8A1, $60 \mathrm{IU} / \mathrm{mg}$ ) was not highly purified, the antiserum probably contains a large number of antibodies. For convenience, we may divide the entire antibody population into those that bind $\mathrm{FSH}^{-131} \mathrm{I}$ and those that do not. Clearly, then, any displacement of $\mathrm{FSH}^{-131} \mathrm{I}$ from its antibody by unlabeled hormone must be due to binding of that unlabeled hormone by the antibody that binds $\mathrm{FSH}^{-131} \mathrm{I}$. Any antibody present in the antiserum that bound unlabeled FSH and any or all of the other three unlabeled hormones but did not bind FSH-131I would still not prevent the displacement of FSH-131 I from its antibody and would in no way alter our conclusion regarding cross-reactivity among the four glycoprotein hormones.

Furthermore, if a significant concentration of an antibody were present that failed to bind both FSH-131 I and unlabeled FSH but did bind TSH, LH, or HCG, such an antibody would act as a "sink" for these three unlabeled hormones, and larger quantities of them would probably be necessary to produce the same displacement of FSH-131I from its antibody as is produced by unlabeled FSH. Since all these four unlabeled hormones, at each concentration, are equally potent in displacing FSH-131 I, the existence of such a hypothetical antibody population is extremely unlikely. This degree of cross-reactivity among the four glycoprotein hormones also minimizes the possibility that immunologically active fragments, undetected by bioassays, are contributing significantly to displacement of hormone from antibody. Our antisera might contain an $\mathrm{FSH}^{-131}$ I-binding antibody that binds FSH much more strongly than it does the other three unlabeled hormones; however, if present, it would represent only a very small fraction of the total antibody (e.g., 5\%). In fact, several 
investigators have found some sera with low concentrations of antibodies that bind FSH much more strongly than the other hormones (14-16).

Franchimont, the first investigator to report a radioimmunoassay of $\mathrm{FSH}$ in plasma, did not report studies of the cross-reaction of $\mathrm{LH}$ and HCG with his antiserum, either by radioimmunoassay or by biological neutralization (17). However, he and others have noted that rabbit antiHCG and rabbit anti-LH bind LH and HCG but react only slightly with $\mathrm{TSH}$ and $\mathrm{FSH}$ (18). Likewise we found that rabbit anti-HCG bound $\mathrm{HCG}^{-131}$ I and LH-131I equally well, and both were displaced identically with unlabeled HCG and LH. FSH was less than one-tenth as potent. Similarly, others have reported that rabbit anti-TSH crossreacts only weakly and incompletely with urinary gonadotropins (a mixture of $\mathrm{FSH}$ and $\mathrm{LH}$ ) and with purified HCG (19). Therefore it would appear that our anti-FSH antibodies have the broadest cross-reactivity of any of the antihormone sera examined thus far. Because experimental conditions and reagents vary among laboratories, further studies are needed before the breadth of specificity of anti-LH, anti-HCG, and anti-TSH sera is definitely established.

Immunological cross-reactivity has been observed and easily explained among hormones known to have regions of identical structures or biological activities in common (e.g., arginine and lysine vasopressin, human growth hormone and human placental lactogen, LH and HCG, adrenocorticotropin and melanocyte-stimulating hormone). However, our finding of a significant cross-reaction of these hormones with at least the vast majority of the $\mathrm{FSH}-{ }^{131} \mathrm{I}$ binding antibody in all of many sera from different animals is striking, particularly since the biological activities of these hormones are distinct, and the chemical differences are well described. These include total carbohydrate content, proportions of individual sugars, inactivation studies and behavior on electrophoresis and on substituted celluloses $(20,21)$.

In view of the poor reactivity of $\mathrm{FSH}$ with the antibody to the other hormones, and the same approximate size of the four hormones ( $\mathrm{mol} \mathrm{wt}$ roughly $30,000-40,000$ ), our findings lead us to suggest that FSH has sites whose peculiar structures endow them with inordinately more immunogenicity than the remainder of the molecule, and these few sites are similar to regions on the other three hormones. Among the less likely possibilities are (a) all four hormones have many regions in common, (b) the FSH molecule, analogous to alpha melanocyte-stimulating hormone and adrenocorticotropin, is represented in toto as a part of the larger structure of the other hormones, (c) $\mathrm{FSH}$ is largely composed of one or a few serially repeating structures that are also found to some extent in the other three hormones.

\section{ACKNOWLEDGMENTS}

Starting in December 1965 Robert M. Blizzard, Director of the National Pituitary Agency of the National Institutes of Health, arranged a series of conferences at which unpublished data were exchanged, and plasmas and hormones were given to participating investigators. The contents of this publication were presented in detail to this group at the June 1966 meeting, and we are grateful to Drs. R. Assan, S. A. Berson, R. M. Blizzard, C. Cargille, C. Faiman, A. R. Midgely Jr., W. D. Odell, L. E. Reichert, G. T. Ross, R. J. Ryan, and B. B. Saxena for data and discussion at these meetings. Dr. P. Franchimont was most kind in sending us his unpublished data. The authors are grateful to Ida Stotler for excellent technical assistance, to the physicians and nursing personnel of Ward 8 West, National Institutes of Health (NIH) Clinical Center, for help with the studies in patients, and to R. D. Zinn and L. D. Stuart for immunization and bleeding of large animals.

\section{REFERENCES}

1. Schlaff, S., S. Rosen, and J. Roth. 1967. Immunoassay of follicle stimulating hormone (FSH) in human plasma. Clin. Res. 15: 265.

2. Berson, S. A., and R. S. Yalow, 1964. Immunoassay of protein hormones. In The Hormones: Physiology, Chemistry, and Applications. G. Pincus, K. V. Thimann, and E. B. Astwood, editors. Academic Press Inc., New York. 4: 557.

3. Steelman, S. L., and F. M. Pohley. 1953. Assay of the follicle stimulating hormone based on the augmentation with human chorionic gonadotropin. Endocrinology. 53: 604.

4. Hunter, W. M., and F. C. Greenwood. 1962. Preparation of Iodine ${ }^{131}$-labelled human growth hormone of high specific activity. Nature. 194: 495.

5. Morgan, C. R., R. L. Sorenson, and A. Lazarow. 1964. Studies of an inhibitor of the two antibody immunoassay system. Diabetes. 13: 1 .

6. Poulik, M. D. 1957. Starch gel electrophoresis in a discontinuous system of buffers. Nature. 180: 1477.

7. Davis, B. J. 1964. Disc electrophoresis. II. Method and application to human serum proteins. Ann. N. Y. Acad. Sci. 121: 404. 
8. Moudgal, N. R., and C. H. Li. 1961. An immunological study of a human pituitary interstitial cellstimulating hormone. Nature. 191: 192.

9. Wide, L.. P. Roos, and C. Gemzell. 1961. Immunological determination of human pituitary luteinizing hormone (LH). Acta Endocrinol. 37: 445.

10. Reichert, F. L., R. I. Pencharz, M. E. Simpson, K. Meyer, and H. M. Evans. 1932. Relative ineffectiveness of prolan in hypophysectomized animals. Am. J. Physiol. 100: 157.

11. Fusco, F. D., and S. W. Rosen. 1966. Gonadotropinproducing anaplastic large cell carcinomas of the lung. New Engl. J. Med. 275 : 507.

12. Berson, S. A., and R. S. Yalow. 1959. Quantitative aspects of the reaction between insulin and insulinbinding antibody. J. Clin. Invest. 38: 1996.

13. Scatchard, G. 1949. The attraction of proteins for small molecules and ions. Ann. N. Y. Acad. Sci. 51: 660.

14. Midgley, A. R., Jr. 1967. Radioimmunoassay for human follicle stimulating hormone (HFSH). J. Clin. Endocrinol. Metab. 27: 295.
15. Faiman, C., and R. J. Ryan. 1967. Radioimmunoassay for human follicle stimulating hormone. J. Clin. Endocrinol. Metab. 27 : 444.

16. Odell, W. D., and A. F. Parlow. 1967. Radioimmunoassay for human follicle stimulating hormone. Clin. Res. 15: 125 .

17. Franchimont, P. 1967. Le Dosage des Hormones Hypophysaires Somatotrope et Gonadotropes et Son Application en Clinique. Arscia S. A., Brussels.

18. Odell, W. D., G. T. Ross, and P. L. Rayford. 1967. Radioimmunoassay for luteinizing hormone in human plasma or serum: physiological studies. J. Clin. Invest. 46: 248.

19. Odell, W. D., J. F. Wilber, and W. E. Paul. 1965. Radioimmunoassay of thyrotropin in human plasma. J. Clin. Endocrinol. Metab. 25: 1179.

20. Spiro, R. G. 1963. Glycoproteins : structure, metabolism and biology. New Engl. J. Med. 269: 566.

21. Wolstenholme, G. E. W., editor. 1965. Gonadotropins : Physicochemical and Immunological Properties. Ciba Foundation Study Group No. 22. Little, Brown and Company, Boston. 